\title{
Utility of hair shafts from study skins for mitochondrial DNA analysis
}

\author{
N. Kurihara \\ Department of Zoology, National Museum of Nature and Science, \\ Tsukuba, Ibaraki, Japan \\ Corresponding author: N. Kurihara \\ E-mail: nozomi-k@kahaku.go.jp
}

Genet. Mol. Res. 12 (4): 5396-5404 (2013)

Received November 23, 2012

Accepted February 25, 2013

Published November 11, 2013

DOI http://dx.doi.org/10.4238/2013.November.11.1

\begin{abstract}
The condition of mtDNA in hair shafts preserved in a museum was examined using 30 study skins of masked palm civets, Paguma larvata (Viverridae), collected between 1924 and 2011. Comparisons of extracts from fresh and burnt alum-fixed hair shafts showed that burnt alum, which is commonly used in taxidermy, had no harmful effect on the amount of total DNA and lengths of the mtDNA fragments. Burnt alum-fixed hair shafts had a tendency to develop a small degree of melanin hindering PCR amplification compared with fresh hair shafts, although that observation was not supported statistically (Wilcoxon signed-rank test, $\mathrm{Z}=-0.183, \mathrm{P}=0.855$ ). However, the amount of total DNA decreased after preparation of specimen in an exponential relation (regression of log DNA amount with year, regression analysis, $\mathrm{F}=7.065, \mathrm{P}=0.013$ ). Nevertheless, the oldest specimen, collected in 1924, yielded $1341.5 \mathrm{ng}$ of DNA per 100 hair shafts, which was sufficient for PCR amplification. In addition, the mtDNA fragment length and amount of melanin in the hair shaft were not significantly correlated with the passage of time after preparation ( $\mathrm{F}$ $=0.244, \mathrm{P}=0.625$ for mtDNA fragment length; $\mathrm{F}=0.039, \mathrm{P}=0.845$ for the amount of melanin). Therefore, hair shafts prepared and preserved by chemical treatment in museums are good sources of mtDNA and
\end{abstract}


useful for genetic analysis.

Key words: Mitochondrial DNA; Hair shaft; Study skin; Genetic analysis; Museum collection; DNA damage

\section{INTRODUCTION}

Many researchers have attempted to extract and amplify mitochondrial DNA (mtDNA) from museum collections, including bones, epithelial tissues from stuffed or study skins, and formalin-fixed specimens (Hall et al., 1997; Shedlock et al., 1997; Pichler et al., 2001; Wisely et al., 2004; Moraes-Barros and Morgante, 2007; Casas-Marce et al., 2010). These techniques are utilized for the genetic analysis of rare or endangered species and for type specimens described long ago that have no accompanying frozen or ethanol-fixed tissues appropriate for genetic analysis. Actually, the genetic analyses of museum collections have provided important data for phylogenetic analyses, evolutionary studies, and conservation genetics (Higuchi et al., 1984; Thomas et al., 1990; Westemeier et al., 1998; Miller and Waits, 2003). However, most of these methods are destructive and lead to a loss of morphological information. Higuchi et al. (1984) succeeded in partially sequencing the mtDNA of an extinct mammalian species, the quagga (Equus quagga). Their technique, however, required $0.7 \mathrm{~g}$ skin. Moraes-Barros and Morgante (2007) used a skin fragment $1.5 \times 0.3 \mathrm{~cm}$ in size to produce sequences from a study skin.

Hairs are also important sources of mtDNA (Higuchi et al., 1988). Hair-based genetic studies have used hair roots, because the root is composed of cells (Pilkington et al., 1987; Sloane et al., 2000). On the other hand, Linch et al. (2001) reported that fragmentized mitochondria in the keratinized cells of hair shafts could be good sources of mtDNA, and some researchers have performed successful sequencing using hair shafts for population genetic investigations, forensic casework, and ancient DNA analyses (Vigilant et al., 1989; Wilson et al., 1995; Gilbert et al., 2007). Although genetic analysis using hair shafts obtained from museum collections has never been reported, hair shafts may be preferable sources of mtDNA because of the following: 1) the number of mitochondria in the cells composing the hair shaft may be higher than that in other museum tissues, including bone and skin (Gilbert et al., 2007); 2) keratinized cells protect mtDNA from contamination by exogenous DNA (Gilbert et al., 2004, 2006); and 3) the degree of damage to the specimen is relatively small. A number of factors could hinder polymerase chain reaction (PCR) amplification using hair shafts obtained from museum collections. For example, the mtDNA in hair shafts decays rapidly post-mortem (Gilbert et al., 2006), suggesting that mtDNA in study skins kept in museums for a long time may be seriously damaged. Also, the chemicals used to fix specimens and for fumigation may damage mtDNA and/or hinder PCR amplification.

In museums, countless hairs are preserved as mounted skins, study skins, stuffed skins, and formalin-fixed specimens. Therefore, greater opportunities for analyzing museum collections, including old specimens and rare or endangered species, may exist, provided that hair shafts are rich sources of mtDNA. Since study skins are one of the main parts of mammalian collections in museums, the utility of hair shafts from study skins as a source of mtDNA was assessed. The amount of DNA, mtDNA fragment length, amount of melanin, which is present in mammalian hair and which hinders PCR amplification, and the effects of burnt alum on hair shaft DNA were investigated, using study skins of masked palm civets (Paguma larvata) collected between 1924 and 2011. 


\section{MATERIAL AND METHODS}

Hair shafts plucked from 30 study skins of masked palm civets (Paguma larvata) were used for the following examinations (Table 1). To confirm the effect of burnt alum, which is commonly used in taxidermy, on DNA, two sources of DNA were extracted from the hair shafts of thirteen specimens collected in 2011: fresh hair shafts and hair shafts plucked from the skin, which was fixed in a solution of burnt alum for 1 day and dried at room temperature for 2 weeks. The amount of total DNA, mtDNA fragment length, and amount of melanin were compared between the two DNA sources. To examine the relationship between DNA damage and the passage of time after preparation, the same points were investigated for 30 study skins collected in $1924-2011$ (Table 1).

\begin{tabular}{|c|c|c|c|c|c|c|}
\hline Museum No. & Year & $\begin{array}{c}\text { Chemicals in } \\
\text { taxidermy }\end{array}$ & Sex & Locality & $\begin{array}{c}\text { Body } \\
\text { length }(\mathrm{cm})\end{array}$ & Remarks \\
\hline NSMT-M 38573 & 2011 & Burnt alum & M & 2-1, Yahara, Nerima-ku, Tokyo, Japan & 88.3 & Road kill \\
\hline NSMT-M 38574 & 2011 & Burnt alum & $\mathrm{F}$ & 1-1-14, Sekimachihigashi, Nerima-ku, Tokyo, Japan & 96.5 & Road kill \\
\hline NSMT-M 38575 & 2011 & Burnt alum & $\mathrm{F}$ & 3, Fujimidai, Nerima-ku, Tokyo, Japan & 87.1 & Road kill \\
\hline NSMT-M 38576 & 2011 & Burnt alum & M & 1-31, Kamitakada, Nakano-ku, Tokyo, Japan & 99.5 & Road kill \\
\hline NSMT-M 38577 & 2011 & Burnt alum & M & 5-29-15, Nishioizumi, Nerima-ku, Tokyo, Japan & 93.5 & Road kill \\
\hline NSMT-M 38578 & 2011 & Burnt alum & M & 3-46, Sekimachikita, Nerima-ku, Tokyo, Japan & 95.3 & Road kill \\
\hline NSMT-M 38579 & 2011 & Burnt alum & $\mathrm{F}$ & 1-12, Takamatsu, Nerima-ku, Tokyo, Japan & 100.0 & Road kill \\
\hline NSMT-M 38580 & 2011 & Burnt alum & $\mathrm{F}$ & 5-30, Kasuga-cho, Nerima-ku, Tokyo, Japan & 93.5 & Road kill \\
\hline NSMT-M 38581 & 2011 & Burnt alum & M & 7-22-41, Shakujiidai, Nerima-ku, Tokyo, Japan & 99.4 & Road kill \\
\hline NSMT-M 39059 & 2011 & Burnt alum & $\mathrm{F}$ & 1-23-23, Takanodai, Nerima-ku, Tokyo, Japan & 93.0 & Road kill \\
\hline NSMT-M 39061 & 2011 & Burnt alum & M & 5-7, Oizumigakuen, Nerima-ku, Tokyo, Japan & 97.7 & Road kill \\
\hline NSMT-M 39062 & 2011 & Burnt alum & M & 6, Hogashioizumi, Nerima-ku, Tokyo, Japan & 99.8 & Road kill \\
\hline NSMT-M 38729 & 2011 & Burnt alum & $\mathrm{F}$ & 2, Shimosyakujii, Nerima-ku, Tokyo, Japan & 96.4 & Road kill \\
\hline NSMT-M 35885 & 2008 & Burnt alum & M & 3-23-1, Hyakunin-cho, Shinjuku-ku, Tokyo, Japan & 74.5 & Capture \\
\hline NSMT-M 35886 & 2008 & Burnt alum & M & 3-23-1, Hyakunin-cho, Shinjuku-ku, Tokyo, Japan & 76.5 & Capture \\
\hline NSMT-M 35887 & 2008 & Burnt alum & $\mathrm{F}$ & 3-23-1, Hyakunin-cho, Shinjuku-ku, Tokyo, Japan & 75.0 & Capture \\
\hline NSMT-M 34484 & 2006 & Burnt alum & $\mathrm{F}$ & Oya, Naraham-machi, Futaba-gun, Fukushima, Japan & 93.5 & - \\
\hline NSMT-M 38121 & 2006 & Burnt alum & M & 1-11-36, Musashinodai, Fussa-shi, Tokyo, Japan & - & Road kill \\
\hline NSMT-M 36805 & 2004 & Burnt alum & $\mathrm{F}$ & Ichinomiya-cho, Toyokawa-shi, Aichi, Japan & 98.0 & Road kill \\
\hline NSMT-M 36808 & 2004 & Burnt alum & $\mathrm{F}$ & Suwanishi-machi, Toyokawa-shi, Aichi, Japan & 84.0 & Capture \\
\hline NSMT-M 36816 & 2004 & Burnt alum & $\mathrm{F}$ & Tarui-cho, Toyokawa-shi, Aichi Japan & 97.5 & Capture \\
\hline NSMT-M 36826 & 2004 & Burnt alum & $\mathrm{F}$ & Hagi-cho, Toyokawa-shi, Aichi, Japan & 97.0 & Capture \\
\hline NSMT-M 36827 & 2004 & Burnt alum & M & Honno-cho, Toyokawa-shi, Aichi, Japan & 97.0 & Capture \\
\hline NSMT-M 36902 & 2004 & Burnt alum & M & Honno-cho, Toyokawa-shi, Aichi, Japan & - & - \\
\hline NSMT-M 36779 & 2002 & Burnt alum & $\mathrm{U}$ & Asuke-cho, Toyota-shi, Aichi, Japan & - & Road kill \\
\hline NSMT-M 36788 & 2002 & Burnt alum & M & Asuke-cho, Toyota-shi, Aichi, Japan & 100.2 & Road kill \\
\hline NSMT-M 25730 & 1985 & Unknown & M & Tanzawa, Kanagawa, Japan & - & - \\
\hline NSMT-M 20345 & 1979 & Unknown & M & Nomura-cho, Seiyo-shi, Ehime, Japan & - & - \\
\hline NSMT-M 08192 & 1960 & Unknown & M & Furudono-machi, Ishikawa-gun, Fukushima, Japan & - & - \\
\hline NSMT-M 12777 & 1924 & Unknown & $\mathrm{U}$ & Taiwan & - & - \\
\hline
\end{tabular}

The plucked hairs were washed in 70\% ethanol before DNA extraction. Total DNA was extracted from 100 hairs (2.5-4 cm in length) per specimen using an IsoHair kit (Nippon Gene Co., Ltd., Toyama, Japan). This method caused no visual damage to the study skins. The amount of total DNA was calculated using the DNA concentration as measured using a NanoDrop ND-1000 spectrophotometer (LMS Co., Ltd., Tokyo, Japan). The amount of melanin in the mixture used for PCR amplification was also measured. Because the quantity of melanin could not be measured directly, the necessary quantity of the T4 gene 32 protein (Nippon Gene Co., Ltd.), which counteracts the negative effects of melanin, to carry out successful PCR amplification was used as an indicator of the amount of melanin. The lengths of the mtDNA fragments were examined by PCR amplification 
using original primer sets to amplify fragments of $282,385,580,682$, and $881 \mathrm{bp}$ of the cytochrome $b$ gene: forward primer, Cy168PL-F: (5'-TCAGACACAGTTACCGCCTTCTCA-3') and five reverse primers, Cy361PL-R: (CTATGAAGGCTGTAGCTATTACTGCAA), Cy553PL-R: (5'-GGCTGAGATGATGAATGGAA-3'), Cy748PL-R: (5'-GGGGTATAGTTGTCTGGGTCT CCTA-3'), Cy850PL-R: (5'-ACTCCTCCTAGTTTGTTGGGAA-3'), and Cy1049PL-R:(5'-GTAGG AGATGGAGGCTAATTGTCCA-3'). PCR was performed in a $10-\mu \mathrm{L}$ reaction volume containing 1.0 $\mu \mathrm{L}$ 10X Ex Taq Buffer (Takara Bio Inc., Shiga, Japan), $0.2 \mathrm{mM}$ dNTPs (Takara Bio Inc.), $0.2 \mu \mathrm{M}$ forward primer, $0.08 \mu \mathrm{M}$ of each reverse primer, $0.5 \mathrm{U}$ Ex Taq (Takara Bio Inc.), $1.0 \mu \mathrm{L}$ template DNA, and 0.5 or $1.0 \mu \mathrm{L}$ T4 gene 32 protein (optional; Nippon Gene Co., Ltd.). Amplification was carried out for a total of 46 cycles. A total of 10 cycles were as follows: $94^{\circ} \mathrm{C}$ for $30 \mathrm{~s}, 40^{\circ} \mathrm{C}$ for $30 \mathrm{~s}$, and $72^{\circ} \mathrm{C}$ for $40 \mathrm{~s}$; and 36 cycles were as follows: $94^{\circ} \mathrm{C}$ for $30 \mathrm{~s}$, $53^{\circ} \mathrm{C}$ for $30 \mathrm{~s}$, and $72^{\circ} \mathrm{C}$ for $40 \mathrm{~s}$.

Statistical analyses were carried out using IBM SPSS Statistics ver. 20 (IBM Co., Armonk, NY, USA). A Wilcoxon signed-rank test was performed to compare the condition of the DNA in the fresh and burnt-alum fixed hair shafts. Regression analysis was also performed to confirm the correlation between DNA condition and the passage of time after preparation.

\section{RESULTS}

The condition of the DNA was compared between extracts from fresh hair shafts and hair shafts treated with burnt alum. The amount of total DNA obtained from fresh hairs averaged $4526.6 \pm 1781.5 \mathrm{ng}$ and ranged between 1851.5 and $8586.5 \mathrm{ng}$. The average and range of the total amount of DNA from the burnt alum-fixed hair shafts were $4040.5 \pm 2018.8$ ng and 995.5-7428.0 ng, respectively. Because both types of extracts had large variations in DNA amount, a significant difference was not detected (Wilcoxon signed-rank test, $\mathrm{Z}=$ $-0.804, \mathrm{P}=0.422$ ). The lengths of the mtDNA fragments that could be amplified by PCR from the fresh hair shafts were between $580-881 \mathrm{bp}$, while those in hair shafts treated with burnt alum were between 282-881 bp (Table 2). Although the minimum lengths of the mtDNA fragments were much shorter in the burnt alum-fixed hairs than in the fresh hair shafts, this difference was not statistically supported (Wilcoxon signed-rank test, $\mathrm{Z}=-1.686, \mathrm{P}=0.092$ ). As for the amount of melanin, there was no significant difference in the necessary quantity of T4 gene 32 protein for successful PCR amplification between the fresh and burnt alum-fixed hair shafts (Wilcoxon signed-rank test, $\mathrm{Z}=-0.183, \mathrm{P}=0.855$ ). However, the fresh samples tended to require more T4 gene 32 protein than the burnt alum-fixed samples (Table 2). Six out of thirteen specimens (NAMT-M 38575, 38577, 38578, 38579, 39059, and 39062) needed more for successful amplification using fresh samples. Four specimens (NSMT-M 38573, 38580,38729 , and 39061) required the same quantity in both samples, and only three specimens (NSMT-M 38573, 38580, and 38581) required it more in the burnt alum-fixed samples.

The change in DNA condition with time after preparation was also investigated. The amount of total DNA was significantly decreased exponentially (regression of log DNA amount with year, regression analysis, $\mathrm{F}=7.065, \mathrm{P}=0.013$ ). The DNA amount was almost constant among specimens collected between 1924 and 1985, and the oldest one contained $1341.5 \mathrm{ng}$ of DNA (Figure 1A). In comparison, the most recent specimens (collected in 2011) showed large variations in the amount of total DNA (Figure 1A). All specimens except for NSMT-M 08192 collected in 1960 and 12777 collected in 1924 were 
Table 2. Length of mtDNA fragment in fresh and burnt alum fixed hairs.

\begin{tabular}{|c|c|c|c|c|c|c|c|c|c|c|c|c|c|c|c|}
\hline \multirow[t]{2}{*}{ Museum No. } & \multirow[t]{2}{*}{ Fresh/burnt alum } & \multicolumn{14}{|c|}{ Length of mtDNA fragment (bp) } \\
\hline & & \multicolumn{2}{|c|}{106} & \multicolumn{2}{|c|}{193} & \multicolumn{2}{|c|}{282} & \multicolumn{2}{|c|}{385} & \multicolumn{2}{|c|}{580} & \multicolumn{2}{|c|}{682} & \multicolumn{2}{|c|}{881} \\
\hline \multirow[t]{2}{*}{ NSMT-M 38573} & Fresh & + & & + & & + & & + & & + & & + & & & \\
\hline & Burnt alum & + & & + & & + & & + & & + & & + & & + & \\
\hline \multirow[t]{2}{*}{ NSMT-M 38574} & Fresh & + & & + & & + & & + & & + & & + & & & \\
\hline & Burnt alum & + & & + & & + & & & & + & $* *$ & & & & \\
\hline \multirow{2}{*}{ NSMT-M 38575} & Fresh & + & & + & & + & & & & + & $* *$ & + & ** & & \\
\hline & Burnt alum & + & $*$ & + & $*$ & + & $*$ & + & $*$ & & & & & & \\
\hline \multirow[t]{2}{*}{ NSMT-M 38576} & Fresh & + & & + & & + & & + & & + & & + & & + & \\
\hline & Burnt alum & + & & + & $* *$ & + & $* *$ & + & $* *$ & + & $* *$ & & & & \\
\hline \multirow[t]{2}{*}{ NSMT-M 38577} & Fresh & + & $* *$ & + & $* *$ & + & $* *$ & + & $* *$ & + & $* *$ & & & & \\
\hline & Burnt alum & + & $*$ & + & $*$ & + & $*$ & + & $*$ & & & & & & \\
\hline \multirow[t]{2}{*}{ NSMT-M 38578} & Fresh & + & & + & & + & & & & + & $* *$ & + & $* *$ & + & $* *$ \\
\hline & Burnt alum & + & & + & & + & & + & & + & & + & & + & \\
\hline \multirow[t]{2}{*}{ NSMT-M 38579} & Fresh & + & & + & $* *$ & + & $* *$ & + & $* *$ & + & $* *$ & + & $* *$ & & \\
\hline & Burnt alum & + & & + & & + & & + & & + & & + & & + & \\
\hline \multirow[t]{2}{*}{ NSMT-M 38580} & Fresh & + & & + & & + & & + & & + & & + & & + & \\
\hline & Burnt alum & + & & + & & + & & + & & + & & + & & & \\
\hline \multirow[t]{2}{*}{ NSMT-M 38581} & Fresh & + & & + & & + & & + & & + & & + & & & \\
\hline & Burnt alum & + & $* *$ & + & $* *$ & + & $* *$ & + & $* *$ & + & $* *$ & & & & \\
\hline \multirow[t]{2}{*}{ NSMT-M 38729} & Fresh & + & & + & & + & & & & + & $* *$ & + & $* *$ & & \\
\hline & Burnt alum & + & & + & $* *$ & + & $* *$ & & & & & & & & \\
\hline \multirow[t]{2}{*}{ NSMT-M 39059} & Fresh & + & $* *$ & + & ** & + & $* *$ & + & $* *$ & + & $* *$ & & & & \\
\hline & Burnt alum & + & $*$ & + & $*$ & + & $*$ & + & $*$ & & & & & & \\
\hline \multirow[t]{2}{*}{ NSMT-M 39061} & Fresh & + & & + & $* *$ & + & ** & + & ** & + & $* *$ & & & & \\
\hline & Burnt alum & + & $* *$ & + & $* *$ & + & $* *$ & + & *** & + & ** & & & & \\
\hline \multirow[t]{2}{*}{ NSMT-M 39062} & Fresh & + & & + & & + & & + & $* *$ & + & ** & + & ** & & \\
\hline & Burnt alum & + & $*$ & + & $*$ & + & * & + & $*$ & & & & & & \\
\hline
\end{tabular}

$+=$ amplified; $*=$ added $0.5 \mu \mathrm{L}$ of T4 gene 32 protein (Nippon Gene, Inc.); ** = added $1.0 \mu \mathrm{L}$ of $\mathrm{T} 432$ protein (Nippon Gene, Inc.).

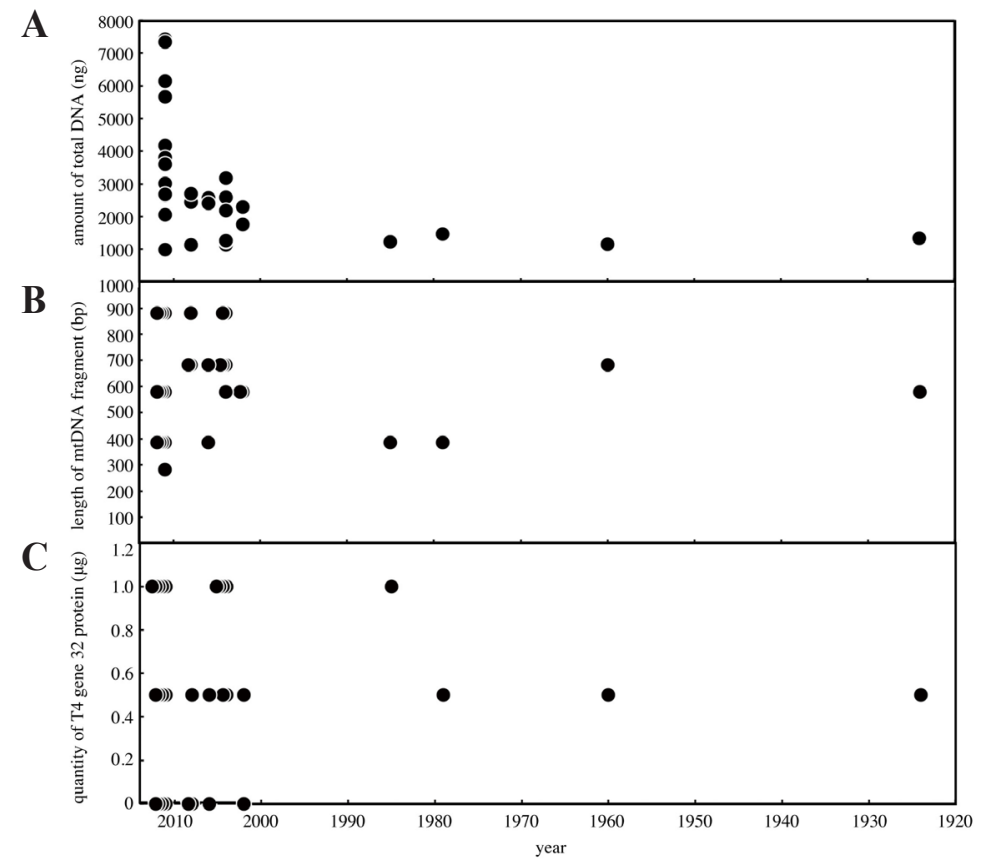

Figure 1. Relationship between the passage of time and: the amount of DNA (A), mtDNA fragment length (B), and the quantity of T4 gene 32 protein $(\mathbf{C})$. 
successfully amplified, confirming the length of the mtDNA fragments when all primer sets were used simultaneously (Figure 2A). The mtDNA from NSMT-M 08192 and 12777 was successfully amplified when each primer set was used separately (Figure 2B). The lengths of the mtDNA fragments ranged $282-881 \mathrm{bp}$ (Figure 1B). Recent specimens collected between 2002 and 2011 had large variations in length; the oldest specimen yielded a product 580 bp in length. Therefore, a significant correlation between mtDNA fragment length

A

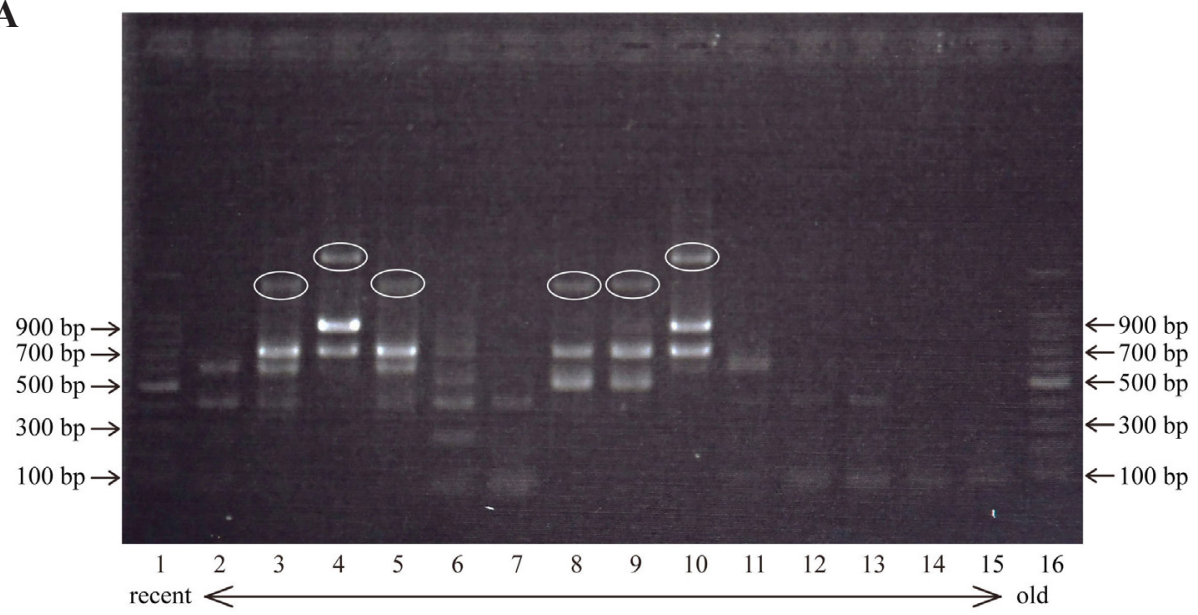

B

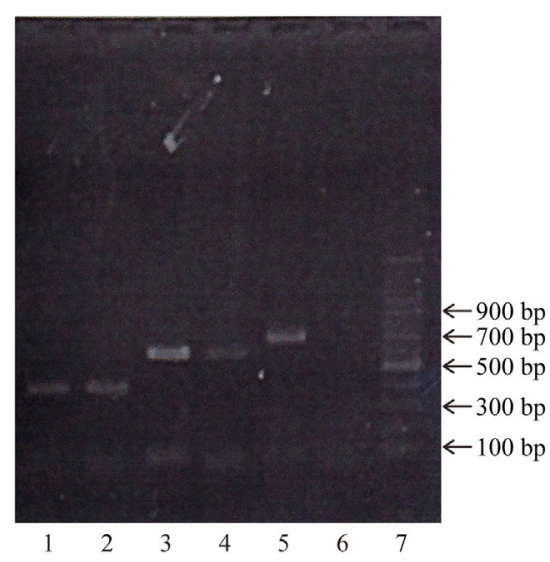

Figure 2. Lengths of mtDNA fragments produced by PCR amplification from 14 appropriately selected specimens. A. Results for 14 specimens when all primer sets were used for amplification. Lanes 1 and $16=$ size markers; lane 2 = NSMT-M 38576 (2011); lane 3 = NSMT-M 38580 (2011); lane 4 = NSMT-M 35886 (2008); lane 5 = NSMT-M 35585 (2008); lane 6 = NSMT-M 38121 (2006); lane 7 = NSMT-M 34484 (2006); lane 8 = NSMT-M 36902 (2004); lane 9 = NSMT-M 36816 (2004); lane 10 = NSMT-M 36805 (2004); lane 11 = NSMT-M 36788 (2002); lane 12 = NSMT-M 25730 (1985); lane 13 = NSMT-M 20345 (1979); lane 14 = NSMT-M08192 (1960); lane 15 = NSMT-M12777 (1924); and ellipse, extra band. B. Results for NSMT-M 08192 (1960) and 12777 (1924) when each primer set was used separately. Lane $1=$ NSMT-M 08192 with the primer set for $385 \mathrm{bp}$; lane 2 = NSMT-M 12777 with the primer set for $385 \mathrm{bp}$; lane $3=$ NSMT-M 08192 with the primer set for $580 \mathrm{bp}$; lane $4=$ NSMT-M 12777 with the primer set for $580 \mathrm{bp}$; lane $5=$ NSMT-M 08192 with the primer set for $682 \mathrm{bp}$; lane $6=$ NSMT-M 12777 with the primer set for $682 \mathrm{bp}$; lane $7=$ size markers. 
and the passage of time after preparation was not detected (regression analysis, $\mathrm{F}=0.244$, $\mathrm{P}=0.625$ ). Although some amplification products had an extra band of high molecular weight, true DNA sequences could be obtained by cutoff of the target band. In addition, the recently collected specimens had large variations in the necessary quantity of T4 gene 32 protein for successful amplification, and there was no correlation between the amount of melanin and the passage of time (Figure $1 \mathrm{C}$, regression analysis, $\mathrm{F}=0.039, \mathrm{P}=0.845$ ).

\section{DISCUSSION}

The chemicals used in the preparation and preservation of museum specimens sometimes inhibit genetic analyses (Hall et al., 1997; Casas-Marce et al., 2010). Kigawa et al. (2003) showed that fumigants such as methyl iodide, propylene oxide, and mixed gases of methyl bromide and ethylene oxide degraded DNA. Bone materials in museums are treated with hydrogen peroxide after boiling (Polanc et al., 2012), and it is well known that hydrogen peroxide damages DNA (Pääbo et al., 2004). In the case of genetic analysis using hair shafts plucked from study skins, it is also thought that burnt alum, which is commonly used in taxidermy, could have harmful effects on DNA and/or PCR amplification. However, contrary to expectations, the amounts and lengths of the DNA fragments did not significantly differ whether the hairs were treated with burnt alum or not (Table 2), showing that burnt alum does not damage DNA in hair shafts. The effect of burnt alum on melanin was also investigated, because it is known that PCR amplification is hindered by water-soluble melanin, which may be produced from insoluble melanin by oxidation (Yoshii et al., 1992, 1993). The results showed that the hairs treated with burnt alum had a tendency to contain smaller quantities of water-soluble melanin than did fresh hairs (Table 2 ), although this was not statistically supported. In addition, the amount of water-soluble melanin did not increase with the passage of time after preparation (Figure 1C). Prota (1988) reported that eumelanin in black human hair is converted to water-soluble eumelanin under alkaline conditions. Therefore, acidic burnt alum perhaps prevents the conversion of insoluble melanin to water-soluble melanin in hair and/or during the process of DNA extraction.

DNA is degraded rapidly after the death of an organism by lysosomal nucleases, bacteria, and fungi (Pääbo et al., 2004). In the case of DNA in hair shafts, Gilbert et al. (2006) reported that DNA degradation was also correlated with histological hair decomposition. Therefore, the observation that the recently collected specimens had large variations in DNA amount probably reflects differences in the degree of DNA degradation progression before preparation of the study skin. DNA amounts also decrease rapidly after preparation (Figure 1A). Fortunately, however, there was an exponential correlation between DNA amount and the passage of time after preparation, meaning that DNA degradation nearly stops after a period of time (Figure 1A). In addition, specimens collected in 1924-1985, in which DNA degradation seems to have stopped, contained enough DNA for successful PCR amplification (Figures 1A and 2). The lack of a correlation between DNA fragment length and the passage of time after preparation is probably explained by the cessation of DNA degradation. This result is attributable to the start of DNA degradation and its continuation at random positions, and to the cessation of degradation at some stage. In addition, it is notable that the oldest specimen, which was collected in 1924 (about 90 years ago), contained mtDNA fragments of $580 \mathrm{bp}$, while it is well known that museum materials, including bone and skin, generally yield DNA fragments of 200-300 bp (Masuda et al., 2009). 
In summary, it was found that hair shafts preserved in museums are rich sources of mtDNA because: 1) the DNA amount in the hair shafts was enough for PCR amplification, 2) DNA degradation in the hair shafts appears to have ceased after a period of time, 3) old specimens yielded longer double-stranded DNA from hair shafts than from other museum materials, 4) the small quantity of water-soluble melanin in the hair shafts did not hinder PCR amplification when using T4 gene 32 protein, and 5) plucking 100 hairs caused no visual damage to the study skins.

\section{ACKNOWLEDGMENTS}

Research supported by JSPS KAKENHI (Grant \#22770088). I thank Drs. Shin-ichiro Kawada, Manami Makara, Tadasu K. Yamada, and Yuko Tajima, and Ms. Hiroko Nagaoka and Ms. Sayaka Shimoinaba at the National Museum of Nature and Science for all of their help. I am grateful to Dr. Shin-ichiro Kawada for providing access to the specimens. I am indebted to Drs. Toshiaki Kuramochi, Takashi P. Sato and Satoru N. Chiba of the National Museum of Nature and Science for providing technical advice on the molecular methods.

\section{REFERENCES}

Casas-Marce M, Revilla E and Godoy JA (2010). Searching for DNA in museum specimens: a comparison of sources in a mammal species. Mol. Ecol. Resour. 10: 502-507.

Gilbert MT, Wilson AS, Bunce M, Hansen AJ, et al. (2004). Ancient mitochondrial DNA from hair. Curr. Biol .14: R463-R464.

Gilbert MT, Menez L, Janaway RC, Tobin DJ, et al. (2006). Resistance of degraded hair shafts to contaminant DNA. Forensic Sci. Int. 156: 208-212.

Gilbert MT, Tomsho LP, Rendulic S, Packard M, et al. (2007). Whole-genome shotgun sequencing of mitochondria from ancient hair shafts. Science 317: 1927-1930.

Hall LM, Willcox MS and Jones DS (1997). Association of enzyme inhibition with methods of museum skin preparation. Biotechniques 22: 928-4.

Higuchi R, Bowman B, Freiberger M, Ryder OA, et al. (1984). DNA sequences from the quagga, an extinct member of the horse family. Nature 312: 282-284.

Higuchi R, von Beroldingen CH, Sensabaugh GF and Erlich HA (1988). DNA typing from single hairs. Nature 332: 543-546.

Kigawa R, Nochide H and Miura S (2003). Effects of various fumigants, thermal methods and carbon dioxide treatment on DNA extraction and amplification: a case study on freeze-dried mushroom and freeze-dried muscle specimens. Collection Forum 18: 74-89.

Linch CA, Whiting DA and Holland MM (2001). Human hair histogenesis for the mitochondrial DNA forensic scientist. J. Forensic Sci. 46: 844-853.

Masuda R, Shimatani Y, Oishi T, Goda N, et al. (2009). Genetic analytical methods for carnivores: Sampling techniques, DNA analysis, data analysis and research case reports. Honyurui Kagaku [translated: Mammalian Science]. (in Japanese) Mamm. Sci. 49: 283-302.

Miller CR and Waits LP (2003). The history of effective population size and genetic diversity in the Yellowstone grizzly (Ursus arctos): implications for conservation. Proc. Natl. Acad. Sci U. S. A. 100: 4334-4339.

Moraes-Barros N and Morgante JS (2007). A simple protocol for extraction and sequence analysis of DNA from study skins of museum collections. Genet. Mol. Biol. 30: 1181-1185.

Pääbo S, Poinar H, Serre D, Jaenicke-Despres V, et al. (2004). Genetic analyses from ancient DNA. Annu. Rev. Genet. 38: 645-679.

Pichler FB, Dalebout ML and Baker CS (2001). Nondestructive DNA extraction from sperm whale teeth and scrimshaw. Mol. Ecol. Notes 1: 106-109.

Pilkington S, Summers C, Thein SL, O'Connor NT, et al. (1987). Hair root DNA: a source of constitutional DNA in leukaemia. Lancet 1: 112 . 
Polanc P, Sindicic M, Jelencic M, Gomercic T, et al. (2012). Genotyping success of historical Eurasian lynx (Lynx lynx L.) samples. Mol. Ecol. Resour. 12: 293-298.

Prota G (1988). Progress in the chemistry of melanins and related metabolites. Med. Res. Rev. 8: 525-556.

Shedlock AM, Haygood MG, Pietsch TW and Bentzen P (1997). Enhanced DNA extraction and PCR amplification of mitochondrial genes from formalin-fixed museum specimens. Biotechniques 22: 394-6, 398, 400.

Sloane MA, Sunnucks P, Alpers D, Beheregaray LB, et al. (2000). Highly reliable genetic identification of individual northern hairy-nosed wombats from single remotely collected hairs: a feasible censusing method. Mol. Ecol. 9: 1233-1240.

Thomas WK, Pääbo S, Villablanca FX and Wilson AC (1990). Spatial and temporal continuity of kangaroo rat populations shown by sequencing mitochondrial DNA from museum specimens. J. Mol. Evol. 31: 101-112.

Vigilant L, Pennington R, Harpending H, Kocher TD, et al. (1989). Mitochondrial DNA sequences in single hairs from a southern African population. Proc. Natl. Acad. Sci. U. S. A. 86: 9350-9354.

Westemeier RL, Brawn JD, Simpson SA, Esker TL, et al. (1998). Tracking the long-term decline and recovery of an isolated population. Science 282: 1695-1698.

Wilson MR, Polanskey D, Butler J, DiZinno JA, et al. (1995). Extraction, PCR amplification and sequencing of mitochondrial DNA from human hair shafts. Biotechniques 18: 662-669.

Wisely SM, Maldonado JE and Fleischer RC (2004). A technique for sampling ancient DNA that minimizes damage to museum specimens. Conserv. Genet. 5: 105-107.

Yoshii T, Tamura K and Ishiyama I (1992). Presence of a PCR-inhibitor in hairs. Nihon Hoigaku Zasshi 46: 313-316.

Yoshii T, Tamura K, Taniguchi T, Akiyama K, et al. (1993). Water-soluble eumelanin as a PCR-inhibitor and a simple method for its removal. Nihon Hoigaku Zasshi 47: 323-329. 